\title{
Heterocycle-fused lupane triterpenoids inhibit Leishmania donovani amastigotes $\uparrow$
}

Cite this: Med. Chem. Commun., 2014, 5,445

Received 29th September 2013 Accepted 20th December 2013

DOI: $10.1039 / c 3 m d 00282 a$

www.rsc.org/medchemcomm

\author{
Raisa Haavikko, ${ }^{a}$ Abedelmajeed Nasereddin, ${ }^{\mathrm{b}}$ Nina Sacerdoti-Sierra, ${ }^{\mathrm{b}}$ \\ Dmitry Kopelyanskiy, ${ }^{\mathrm{b}}$ Sami Alakurtti, ${ }^{\mathrm{c}}$ Mari Tikka, ${ }^{a}$ Charles L. Jaffe $t^{\mathrm{b}}$ and Jari Yli- \\ Kauhaluoma*a
}

\begin{abstract}
The synthesis of heterocyclic betulin derivatives and their activity against Leishmania donovani is reported. Betulonic acid was used as a versatile intermediate. Several different fused heterocycles were introduced at the 2,3-position of the lupane skeleton including isoxazole, pyrazine, pyridine, indole and pyrazole rings. Also the 28-position was modified. Three compounds, 5, 8 and 25, showed low micromolar activity with $I_{50}$ values of $13.2,4.3$ and $7.2 \mu \mathrm{M}$, respectively. Compound 8 showed the best activity and selectivity, and its activity was tested on infected macrophages using a concentration, $5 \mu \mathrm{M}$, where no macrophage toxicity was exhibited. Interestingly, the activity of compound 8 on axenic amastigotes and Leishmaniainfected macrophages was similar.
\end{abstract}

\section{Introduction}

Leishmaniasis is a spectrum of diseases caused by over 20 species of protozoan parasites belonging to the genus Leishmania. These diseases affect people in more than 88 countries. There are an estimated 1-2 million new cases every year, 12 million people currently infected, and 350 million people living in endemic areas at risk. ${ }^{\mathbf{1} 2}$ During the past ten years leishmaniasis has spread considerably. ${ }^{2}$ It is transmitted by the bite of infected female Phlebotomine or Lutzomyia sandflies in the Old World and the New World, respectively. ${ }^{3}$

There are three major forms of leishmaniasis: cutaneous, mucocutaneous, and visceral disease. ${ }^{2,4}$ Cutaneous leishmaniasis is the mildest form of this disease and is characterized by skin ulcers on exposed areas at the site of the sand fly bite. The ulcers generally self-heal leaving scars after a few months to years. In the mucocutaneous form, which is difficult to treat, disfiguring lesions destroy the mucous membranes of the nose, mouth and throat cavity. Finally, visceral leishmaniasis (VL), the most severe form of the disease, is fatal if untreated. VL causes fever, weight loss, anaemia, and enlargement of the spleen and

\footnotetext{
${ }^{a}$ Faculty of Pharmacy, Division of Pharmaceutical Chemistry, University of Helsinki, Viikinkaari 5 E, P. O. Box 56, FI-00014, Helsinki, Finland. E-mail: jari. yli-kauhaluoma@helsinki.fi; Tel: +358-9-19159170

${ }^{b}$ Department of Microbiology and Molecular Genetics, IMRIC, Hebrew UniversityHadassah Medical School, P. O. Box 12272, Jerusalem 91120, Israel. E-mail: cjaffe@cc.huji.ac.il; Tel: +97226757435

${ }^{c}$ VTT Technical Research Centre of Finland, P. O. Box 1000 FI-02044 VTT, Espoo, Finland

$\dagger$ Electronic supplementary information (ESI) available: Experimental procedures, characterization data, ${ }^{1} \mathrm{H}$ and ${ }^{13} \mathrm{C}$ NMR spectra. See DOI: $10.1039 / \mathrm{c} 3 \mathrm{md} 00282 \mathrm{a}$

\$ CLJ holds the Michael and Penny Feiwel Chair of Dermatology.
}

liver. Several treatments exist for leishmaniasis, but most of them have adverse effects. Pentavalent antimonials, the firstline treatment for leishmaniasis, have lost their efficacy in some regions endemic for $\mathrm{VL},{ }^{5}$ and liposomal amphotericin $\mathrm{B}$ is highly expensive. These treatments are administrated by injection and require clinical supervision or hospitalization. Miltefosine, the first effective orally administrated drug for leishmaniasis, is contraindicated in women of child-bearing age due to teratogenic effects. ${ }^{6}$ Hence, there is an urgent need to develop new, safe and effective treatments for these diseases.

Betulin is a plentiful naturally occurring lupane-type pentacyclic triterpene. Betulinic acid and other betulin derivatives show antiviral, ${ }^{7}$ anti-HIV ${ }^{8}$ anti-inflammatory, ${ }^{9}$ anti-malarial, ${ }^{10}$ and anti-tumoral ${ }^{\mathbf{1 1}}$ effects. Previously our group has shown that heterocyclic betulin derivatives have an effect against $L$. donovani amastigotes, which cause VL. ${ }^{12}$ In this study we describe a new set of heterocyclic betulin derivatives and their biological activity against Leishmania donovani amastigotes, as well as the structure-activity relationships of the compounds.

\section{Results and discussion}

\section{Chemistry}

First, betulin 1 was subjected to Jones oxidation, and the resulting betulonic acid 2 was used as a key intermediate for the synthesis of several heterocyclic adducts (Scheme 1). The indole derivatives $\mathbf{3}$ and $\mathbf{4}$ were prepared by the Fischer indole synthesis in $21-42 \%$ yields. Letting betulonic acid react with ethylenediamine in the presence of sulfur and morpholine gave lupa-2,20(29)-dieno[2,3-b] pyrazin-28-oic acid 5 in $68 \%$ yield. ${ }^{13}$ This was treated with oxalyl chloride in dichloromethane (DCM) and the resulting acyl chloride was converted to the primary 


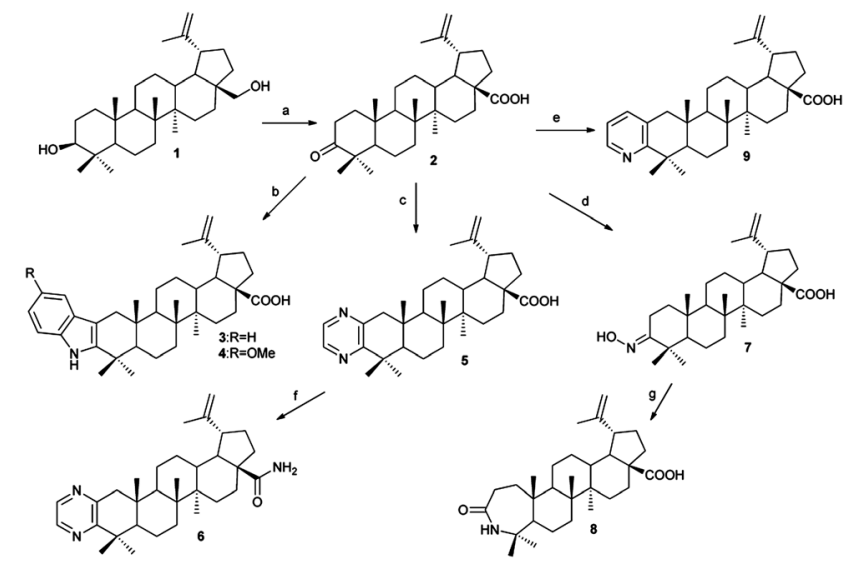

Scheme 1 Reagents and conditions: (a) Jones oxidation, $\mathrm{Na}_{2} \mathrm{Cr}_{2} \mathrm{O}_{7}$, $\mathrm{H}_{2} \mathrm{SO}_{4}, \mathrm{H}_{2} \mathrm{O}$, acetone, rt, $21 \mathrm{~h}, 44 \%$; (b) appropriate phenylhydrazine hydrochloride, HOAc, reflux, 3 h, 21-42\%; (c) ethylenediamine, sulfur, morpholine, reflux, $21 \mathrm{~h}, 68 \%$; (d) $\mathrm{NH}_{2} \mathrm{OH} \cdot \mathrm{HCl}$, pyridine, $\mathrm{MeOH}$, reflux, 16 h, 84\%; (e) propargylamine, $\mathrm{Cu}(\mathrm{I}) \mathrm{Cl}, \mathrm{EtOH}$, reflux, 17 h, 11\%; (f) 1. oxalyl chloride, DCM, rt, $3 \mathrm{~h} ; 2$. aqueous ammonia, DCM, rt, $1 \mathrm{~h}$, quant.; (g) TFAA, DCM, rt, 20 h, 33\%. DCM = dichloromethane, TFAA = trifluoroacetic anhydride.

amide 6 quantitatively by aqueous ammonia in chloroform. ${ }^{\mathbf{1 4}} 3$ Oximinolup-20(29)-en-28-oic acid 7 was obtained by refluxing betulonic acid in the presence of $\mathrm{NH}_{2} \mathrm{OH} \cdot \mathrm{HCl}$ and pyridine in methanol. The oxime 7 was further converted to 4-aza-3-oxohomolup-20(29)-en-28-oic acid 8 in 33\% yield in the Beckmann rearrangement reaction by treating it with trifluoroacetic anhydride (TFAA) in DCM. Lupa-2,20(29)-dieno[2,3-b]pyridin28-oic acid 9 was obtained from the reaction of betulonic acid and propargylamine in the presence of $\mathrm{Cu}(\mathrm{I}) \mathrm{Cl}$ in ethanol in $11 \%$ yield. ${ }^{15}$

The corresponding isoxazole $\mathbf{1 0}$ and pyrazole $\mathbf{1 1}$ derivatives were synthesized via the 2-hydroxymethylene adduct 12 of betulonic acid 2 followed by the condensation/cyclization reaction with $\mathrm{NH}_{2} \mathrm{OH} \cdot \mathrm{HCl}^{16}$ or $\mathrm{H}_{2} \mathrm{NNH}_{2} \cdot \mathrm{H}_{2} \mathrm{O}^{17}$ in $68 \%$ and $80 \%$ yields, respectively (Scheme 2). The carboxyl group of lupa2,20(29)-dieno[2,3-d] isoxazol-28-oic acid 10 was converted to the primary amide functionality $\mathbf{1 3}$ as described above in the case of compound $\mathbf{6 .}^{\mathbf{1 4}}$

20(29)-Dihydrolup-2-en[2,3- $d]$ isoxazol-28-oic acid 14 was obtained from benzyl betulonate in three steps (Scheme 3).

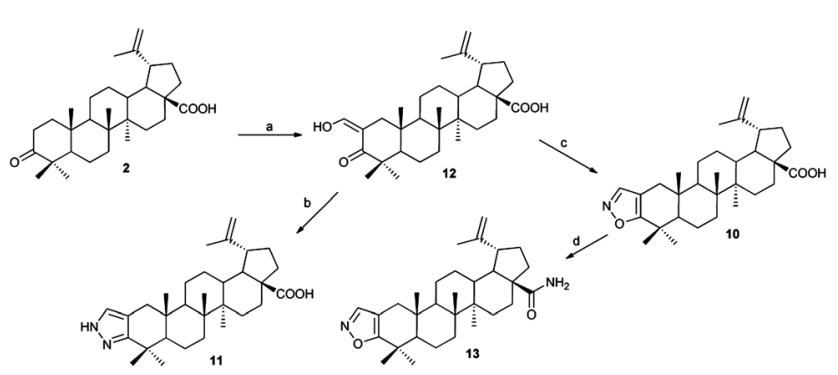

Scheme 2 Reagents and conditions: (a) ethyl formate, NaH, THF, rt, 16 h, 56\%; (b) $\mathrm{H}_{2} \mathrm{NNH}_{2} \cdot \mathrm{H}_{2} \mathrm{O}, p-\mathrm{TsOH}, \mathrm{PhMe}, 150{ }^{\circ} \mathrm{C}, 17 \mathrm{~h}, 80 \%$; (c) $\mathrm{NH}_{2} \mathrm{OH} \cdot \mathrm{HCl}, \mathrm{HOAc}$, reflux, $3 \mathrm{~h}, 68 \%$; (d) 1. oxalyl chloride, DCM, rt, $1 \mathrm{~h}$; 2. aqueous ammonia, $\mathrm{CHCl}_{3}, \mathrm{rt}, 30 \mathrm{~min}$, quant. $\mathrm{THF}=$ tetrahydrofuran.

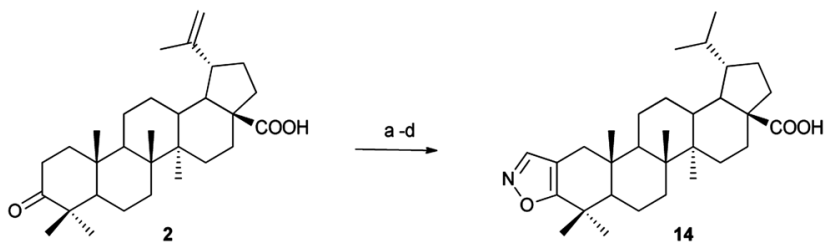

Scheme 3 Reagents and conditions: (a) benzyl bromide, $\mathrm{K}_{2} \mathrm{CO}_{3}, \mathrm{DMF}$, $55^{\circ} \mathrm{C}, 22 \mathrm{~h}, 43 \%$; (b) $\mathrm{H}_{2}, 10 \% \mathrm{Pd} / \mathrm{C}$, EtOAc, rt, $72 \mathrm{~h}$, quant.; (c) ethyl formate, $\mathrm{NaH}, \mathrm{THF}, \mathrm{rt}, 22 \mathrm{~h}, 56 \%$; (d) $\mathrm{NH}_{2} \mathrm{OH} \cdot \mathrm{HCl}, \mathrm{HOAc}$, reflux, $6 \mathrm{~h}$, $90 \%$. DMF $=N, N$-dimethylformamide.

First, the carbon-carbon double bond of benzyl betulonate was reduced under a hydrogen atmosphere in the presence of palladium on carbon in ethyl acetate to give the corresponding dihydrobetulonic acid in $77 \%$ yield. The subsequent Claisen condensation with ethyl formate produced 2-(hydroxymethylene)-3-oxo-20(29)-dihydrolupen-28-oic acid in 56\% yield. Finally, the treatment of the Claisen product with $\mathrm{NH}_{2} \mathrm{OH} \cdot \mathrm{HCl}$ in acetic acid gave the target 20(29)-dihydrolup-2-en[2,3- $d$ ]isoxazol-28-oic acid 14 in $90 \%$ yield.

28-Hydroxylupa-2,20(29)-dieno[2,3- $d]$ isoxazole 15 was synthesized from betulin 1 in five steps (Scheme 4). First, the betulin C-28 hydroxy group was protected as a tetrahydropyranyl ether 16 in $80 \%$ yield, and the resulting THP ether was oxidized to the THP-protected betulonic alcohol with PCC in $\mathrm{DCM}^{18}$ in $46 \%$ yield. Subsequently, the same cascade of reactions as described above for lupa-2,20(29)-dieno[2,3- $d$ ]isoxazol28-oic acid 10 was used to produce the isoxazole-fused 28$O$-acetyl triterpene 17 in $26 \%$ yield over two steps (Scheme 4). In acidic conditions of the cyclization reaction the THP protecting group was cleaved and replaced with the acetoxy group. The acetoxy group was removed with $p$ - $\mathrm{TsOH}$ in methanol in quantitative yield. Finally, 28-hydroxylupa-2,20(29)-dieno[2,3- $d]$ isoxazole 15 was treated with 2-iodoxybenzoic acid in THF and DMSO to give 28-oxolupa-2,20(29)-dieno[2,3-d] isoxazole 18 in $51 \%$ yield.

Allobetulin 19 was obtained in $25 \%$ yield by refluxing betulin 1 in formic acid followed by refluxing the resulting intermediate formate ester in ethanolic solution of $\mathrm{KOH}$ in benzene (Scheme 5). The indole derivatives of allobetulin 20-21 were

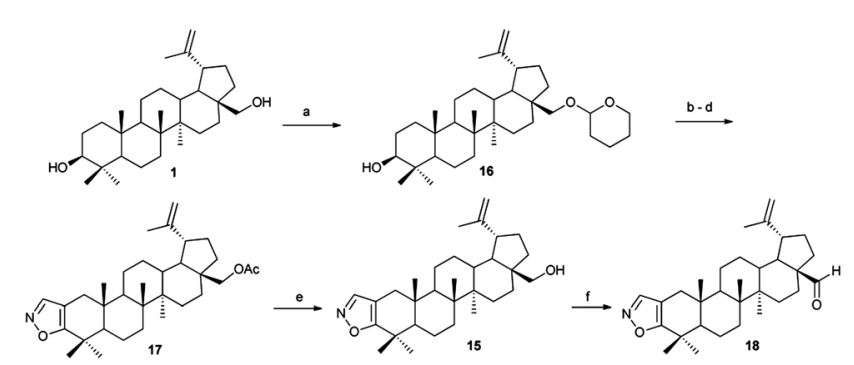

Scheme 4 Reagents and conditions: (a) pyridine $p$-toluenesulfonate, 3,4-dihydro-2H-pyran, DCM, rt, 18 h, 80\%; (b) PCC, DCM, rt, overnight, $46 \%$; (c) ethyl formate, $\mathrm{NaH}, \mathrm{THF}, \mathrm{rt}, 22 \mathrm{~h}, 52 \%$; (d) $\mathrm{NH}_{2} \mathrm{OH} \cdot \mathrm{HCl}, \mathrm{HOAc}$, reflux, $4 \mathrm{~h}$, quant.; (e) $p-\mathrm{TsOH}, \mathrm{MeOH}$, reflux, $20 \mathrm{~h}$, quant.; (f) IBX, THF, DMSO, rt, $3.5 \mathrm{~h}, 51 \%$. $\mathrm{PCC}=$ pyridinium chlorochromate, $\mathrm{IBX}=$ 2-iodoxybenzoic acid, DMSO = dimethyl sulfoxide. 


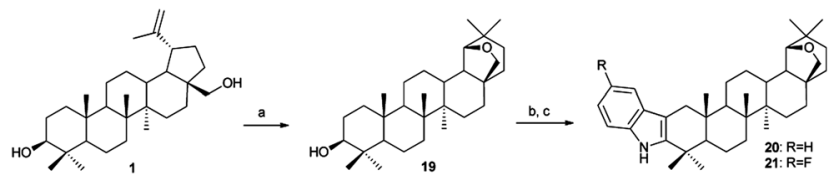

Scheme 5 Reagents and conditions: (a) formic acid, reflux, 45 min; 1 $\mathrm{M} \mathrm{KOH}$ in EtOH, benzene, 30 min, 25\%; (b) Jones oxidation, $21 \mathrm{~h}, 88 \%$; (c) appropriate phenylhydrazine hydrochloride, HOAc, reflux, 2 h, 57$63 \%$.

obtained with the same methodology as described above for betulonic acid ( $c f$. synthesis of compounds 3 and 4) in 57-63\% yields.

Betulonic aldehyde 22 was obtained from betulin 1 by PCC oxidation in DCM in 27\% yield (Scheme 6). 28-Oxolupa-2,20(29)dieno[2,3-b]pyrazine 23 was synthesized in $17 \%$ yield using the same methods as in the preparation of lupa-2,20(29)-dieno[2,3$b]$ pyrazin-28-oic acid 5. It was further reacted with $\mathrm{NH}_{2} \mathrm{OH} \cdot \mathrm{HCl}$ to give 28-oximinolupa-2,20(29)-dien[2,3-b]pyrazine 24 in $77 \%$ yield.

3 $\beta$-(3-Carboxy-3-methylbutanoyloxy)lup-20(29)-en-28-oic acid (bevirimat) 25 was synthesized from betulinic acid 26 by refluxing it in the presence of 2,2-dimethylsuccinic anhydride and DIPEA in DMF for 2 days in 5\% yield (Scheme 7).

\section{Biology and structure-activity relationships}

Previously we found a set of heterocyclic betulin derivatives to have promising activity against axenic amastigotes of L. donovani, ${ }^{12}$ and based on those results we synthesized a new
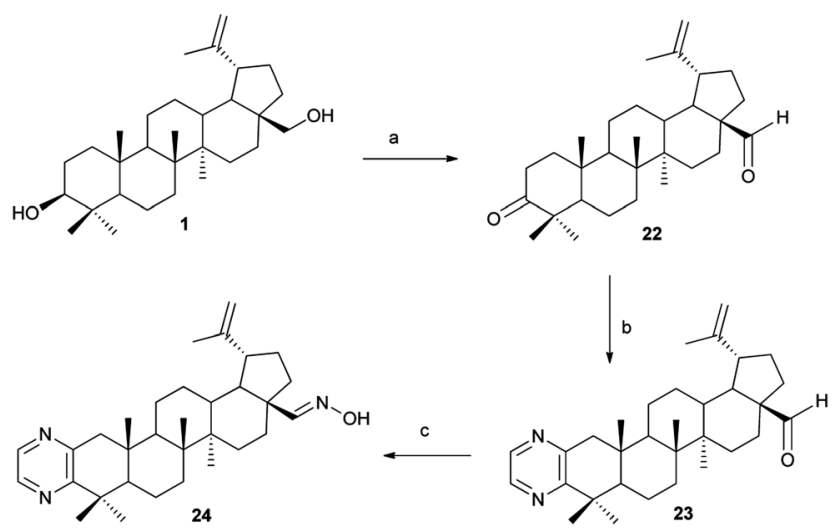

Scheme 6 Reagents and conditions: (a) PCC, DCM, rt, $1 \mathrm{~h}, 27 \%$; (b) ethylenediamine, sulfur, morpholine, reflux, $2.5 \mathrm{~h}, 17 \%$; (c) $\mathrm{NH}_{2} \mathrm{OH} \cdot \mathrm{HCl}$, pyridine-EtOH (1:3), reflux, 16 h, $77 \%$.

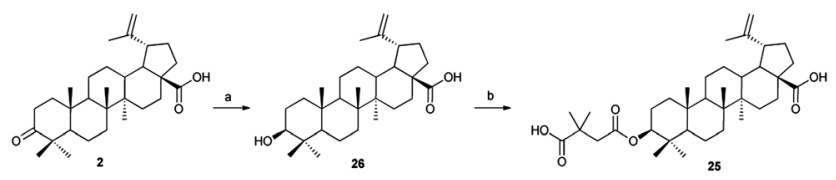

Scheme 7 Reagents and conditions: (a) $\mathrm{NaBH}_{4}, 2$-propanol, rt; (b) 2,2dimethylsuccinic anhydride, DIPEA, DMF $170^{\circ} \mathrm{C}, 2$ days, 5\%. DIPEA = $\mathrm{N}, \mathrm{N}$-diisopropylethylamine. set of fused heterocyclic adducts of betulin, betulinic acid and betulonic acid, and varied substituents at the position C-28 to explore effects of that position as well. Leishmanicidal activity of the modified compounds was assayed using the alamarBlue (AbD Serotec, Oxford, UK) viability assay on axenic amastigotes of L. donovani (Table 1).

Primary screening was performed at $50 \mu \mathrm{M}$ concentration and compounds showing $>70 \%$ inhibition were assayed at $15 \mu \mathrm{M}$ concentration and finally most potent derivatives at $5 \mu \mathrm{M}$ concentration (Table 1 ).

In the series of A-ring fused isoxazoles, the betulin-derived compound 15 had $57 \%$ inhibition of the growth at $50 \mu \mathrm{M}$ concentration. The betulinic acid-derived isoxazole 10 inhibits $96 \%$ at $50 \mu \mathrm{M}$ and $16 \%$ at $15 \mu \mathrm{M}$. Interestingly, the dihydrobetulinic acid-derived isoxazole $\mathbf{1 4}$ had only $3 \%$ inhibition at $50 \mu \mathrm{M}$. In our earlier studies we found a similar effect, but not this strong, between betulonic acid and dihydrobetulonic acid. ${ }^{19}$ The primary amide derivative of the betulinic acidderived isoxazole 13 inhibits $84 \%$ of the growth at $50 \mu \mathrm{M}$ concentration, but only $17 \%$ at $15 \mu \mathrm{M}$ concentration. On the other hand, the betulinic aldehyde-derived isoxazole 18 has lower activity (34\%) at $50 \mu \mathrm{M}$ but slightly better activity $(21 \%)$ at $15 \mu \mathrm{M}$ concentration compared to 13 . This may be due to solubility, as the aldehyde might not be completely soluble at high concentration. The least active isoxazole derivative, 28-O-acetylbetulin-derived isoxazole 17 inhibited only $6 \%$ of the growth at $50 \mu \mathrm{M}$ concentration. It has been suggested that the carboxyl group in the triterpenoid skeleton enhances

Table 1 Activity of the compounds against axenic amastigotes of Leishmania donovani

\begin{tabular}{|c|c|c|c|c|}
\hline \multirow[b]{2}{*}{ Compound } & \multicolumn{3}{|c|}{$\%$ Inhibition \pm s. e. ${ }^{b}$} & \multirow[b]{2}{*}{$\begin{array}{l}\mathrm{IC}_{50} \mu \mathrm{M} \\
\pm \text { s. e. }\end{array}$} \\
\hline & $50 \mu \mathrm{M}$ & $\begin{array}{l}15 \mu \mathrm{M} \\
(\mu \mathrm{M} \pm \text { s. e. })\end{array}$ & $5 \mu \mathrm{M}$ & \\
\hline 2 & $98.6 \pm 0.1$ & $45.9 \pm 0.7$ & - & - \\
\hline 3 & $23.4 \pm 2.2$ & $27.4 \pm 2.4$ & $5.0 \pm 4.4$ & - \\
\hline 4 & $29.3 \pm 4.1$ & $17.5 \pm 2.7$ & $14.0 \pm 2.0$ & - \\
\hline 5 & $92.7 \pm 0.1$ & $79.7 \pm 0.4$ & $20.3 \pm 0.4$ & $13.2 \pm 1.4$ \\
\hline 6 & $94.9 \pm 0.2$ & $35.2 \pm 1.4$ & - & - \\
\hline 8 & $98.2 \pm 0.1$ & $75.2 \pm 1.1$ & $52.0 \pm 1.2$ & $4.3 \pm 0.4$ \\
\hline 9 & $87.9 \pm 0.5$ & $25.6 \pm 1.5$ & - & - \\
\hline 10 & $95.7 \pm 0.3$ & $15.6 \pm 1.0$ & - & - \\
\hline 11 & $60.2 \pm 0.7^{a}$ & - & - & - \\
\hline 13 & $84.3 \pm 0.8$ & $16.7 \pm 2.0$ & - & - \\
\hline 14 & $2.4 \pm 3.4$ & - & - & - \\
\hline 15 & $56.9 \pm 0.4$ & - & - & - \\
\hline 17 & $6.1 \pm 3.7$ & - & - & - \\
\hline 18 & $34.2 \pm 2.0$ & $21.1 \pm 1.1$ & - & - \\
\hline 20 & $19.8 \pm 2.4$ & $18.5 \pm 0.8$ & - & - \\
\hline 21 & $6.8 \pm 0.7$ & $10.2 \pm 4.1$ & $0.2 \pm 1.3$ & - \\
\hline 24 & $2.8 \pm 4.5$ & - & - & - \\
\hline 25 & $100.4 \pm 0.1$ & $69.1 \pm 3.1$ & $59.0 \pm 0.4$ & $7.2 \pm 0.2$ \\
\hline 26 & $61.1 \pm 0.6^{a}$ & - & - & - \\
\hline Amphotericin B & - & - & $99.9 \pm 0.3$ & - \\
\hline Medium alone & $0.0 \pm 4.6$ & $1.5 \pm 3.8$ & $0.0 \pm 0.9$ & - \\
\hline
\end{tabular}

${ }^{a}$ Precipitates at $50 \mu \mathrm{M}$, see crystals. ${ }^{b}$ Average inhibition of triplicates. ${ }^{c}$ Average of two experiments; amphotericin B is a positive control and was tested at $1 \mu \mathrm{M}$. 
the observed antiprotozoal effects. ${ }^{20}$ However, among these A-ring fused isoxazole derivatives of betulin, the compounds $\mathbf{1 8}$ and 13 were more active than the betulinic acid-derived isoxazole 10. All isoxazole derivatives were less active than betulonic acid $2(99 \%$ at $50 \mu \mathrm{M}, 46 \%$ at $15 \mu \mathrm{M})$.

The A-ring fused pyrazine derivative of betulinic acid 5 showed $93 \%$ at $50 \mu \mathrm{M}, 80 \%$ at $15 \mu \mathrm{M}$, and $20 \%$ inhibition at $5 \mu \mathrm{M}$ concentration, whereas for the corresponding primary amide $\mathbf{6}$, we observed inhibition of $95 \%$ at $50 \mu \mathrm{M}$, and $35 \%$ at $15 \mu \mathrm{M}$ concentration, and for its 28 -oximino derivative 24 only $3 \%$ at 50 $\mu \mathrm{M}$. Interestingly, the A-ring fused pyridine derivative of betulinic acid 9 inhibited $88 \%$ at $50 \mu \mathrm{M}$, but only $26 \%$ at $15 \mu \mathrm{M}$ concentration. Here, with pyrazine derivatives, we could see the importance of the carboxyl group for antileishmanial activity.

The A-ring fused $5^{\prime}$-methoxyindole derivative of betulinic acid 4 was the most active indole derivative. At $5 \mu \mathrm{M}$, the lowest concentration tested, inhibition was $14 \%$, whereas the corresponding unsubstituted indole derivative 3 inhibited only $5 \%$. Also with the related indole derivatives the importance of the carboxyl group can be seen as the A-ring fused indole derivative of allobetulin 20 and the corresponding 5 -fluoroindole derivative 21 did not have activity at all. One factor affecting this might be the reduced solubility; allobetulin derivatives are not that soluble under the assay conditions. In addition, the A-ring fused pyrazole derivative of betulinic acid 11 and betulinic acid 26 precipitated at $50 \mu \mathrm{M}$ in these assays.

4-Aza-3-oxohomobetulinic acid $\mathbf{8}$ displayed very good activity (98\%) at $50 \mu \mathrm{M}$ concentration and even at $5 \mu \mathrm{M}$ concentration (inhibition 52\%), whereas the A-ring fused pyrazole derivative of betulinic acid 11 displayed moderate $60.2 \%$ inhibition at $50 \mu \mathrm{M}$ concentration. In addition, potent anti-HIV betulinic acid derived compound 25, bevirimat, displayed very good inhibition: $100 \%$ inhibition at $50 \mu \mathrm{M}$ concentration and $59 \%$ at $5 \mu \mathrm{M}$ concentration. The best compounds after primary screening were compounds 5, 8 and 25 that significantly inhibited parasite growth when tested at lower concentrations. The $\mathrm{IC}_{50}$ values for 5, 8 and 25 were 13.2, 4.3 and $7.2 \mu \mathrm{M}$, respectively, with compound 8 showing the best activity. Cytotoxicity $\mathrm{IC}_{50}$ values of 8 and 25 against THP-1 cell line were 55.5 and $54.0 \mu \mathrm{M}$, respectively. Compound 25 (bevirimat) showed the highest activity among the compounds tested in this study. It showed $100 \%$ inhibition at $50 \mu \mathrm{M}, 69 \%$ at $15 \mu \mathrm{M}$, and $59 \%$ at $5 \mu \mathrm{M}$. Interestingly, bevirimat 25 also showed good activity against HIV-infected patients in a recent phase II study. ${ }^{21}$ Only 4-aza-3oxohomobetulinic acid 8 showed a similar level of activity with $98 \%$ inhibition at $50 \mu \mathrm{M}, 75 \%$ at $15 \mu \mathrm{M}$, and $52 \%$ at $5 \mu \mathrm{M}$. The third most active compound was the A-ring fused pyrazine derivative of betulinic acid 5. Cytotoxicity (Table 2) using the human macrophage cell line THP-1 was determined for 8 and 25, and found to be similar ( $\mathrm{IC}_{50} \quad c a .50 \mu \mathrm{M}$ ) for both compounds. Compound $\mathbf{8}$ had the best selectivity index $\left(\mathrm{IC}_{50} \mathrm{THP}-1 / \mathrm{IC}_{50}\right.$ axenic amastigotes; $\left.\mathrm{SI}=12.9\right)$, and its activity was tested on $L$. donovani-infected macrophages at low $5 \mu \mathrm{M}$ concentration, where no macrophage toxicity was observed. Interestingly, activity of the compound $\mathbf{8}$ against Leishmania infected macrophages $(54.0 \pm 4.8 \%$ inhibition $)$ was similar to that seen for axenic amastigotes $(52.0 \pm 1.2 \%$ inhibition $)$.
Table 2 Toxicity for THP-1 macrophages, and activity against Leishmania donovani infected macrophages (iM $\Phi$ )

\begin{tabular}{|c|c|c|c|}
\hline Compound & $\begin{array}{l}\text { Toxicity for THP-1 } \\
\text { cells }^{a} \mathrm{IC}_{50} \\
(\mu \mathrm{M} \pm \text { s. e. })\end{array}$ & $\mathrm{SI}^{b}$ & $\begin{array}{l}\% \text { inhibition } \pm \text { s. e. of } \\
\text { parasites in } \operatorname{iM}^{c} \\
5 \mu \mathrm{M}\end{array}$ \\
\hline 8 & $55.5 \pm 1.8$ & 12.9 & $54.0 \pm 4.8$ \\
\hline 25 & $54.0 \pm 1.7$ & 7.5 & nd \\
\hline $\begin{array}{l}\text { Amphotericin } \\
\text { B }\end{array}$ & nd & nd & $96.7 \pm 0.7$ \\
\hline
\end{tabular}

\section{Experimental section}

\section{Chemistry}

1'H-Lupa-2,20(29)-dieno[3,2-b]indol-28-oic acid (3). Betulonic acid $(0.10 \mathrm{~g}, 0.22 \mathrm{mmol})$ and the corresponding phenylhydrazine hydrochloride $(0.35 \mathrm{~g}, 0.24 \mathrm{mmol})$ were dissolved in acetic acid $(10 \mathrm{~mL})$ and refluxed $\left(130{ }^{\circ} \mathrm{C}\right)$ for $3 \mathrm{~h}$. Water was added and the resulting mixture was extracted with $\mathrm{Et}_{2} \mathrm{O}$. The organic phase was washed with water and brine, dried over anhydrous $\mathrm{Na}_{2} \mathrm{SO}_{4}$, and the solvents were evaporated. The crude product was purified by $\mathrm{SiO}_{2}$ column chromatography (25-50\% EtOAc- $n$-hexane) to give a yellowish solid (49 mg, 42\%). ${ }^{1} \mathrm{H}$ NMR $\left(300 \mathrm{MHz}, \mathrm{CDCl}_{3}\right) \delta 7.71(\mathrm{~s}, 1 \mathrm{H}), 7.37(\mathrm{~m}, 1 \mathrm{H}), 7.29(\mathrm{~m}, 1 \mathrm{H}), 7.08$ (m, 2H), 4.79 (s, 1H), 4.65 (s, 1H), 3.08 (m, 1H), 2.83 (d, J= 15.0 $\mathrm{Hz}, 1 \mathrm{H}), 2.38-2.09$ (m, 4H), 1.73 (s, 3H), 1.68-1.31 (m, 12H), 1.28 (s, 3H), 1.17 (s, 3H), 1.05 (s, 3H), $1.04(\mathrm{~s}, 3 \mathrm{H}), 0.88(\mathrm{~s}, 3 \mathrm{H}) ;{ }^{13} \mathrm{C}$ NMR (75 MHz, $\mathrm{CDCl}_{3}$ ) $\delta 181.7,150.4,140.9,136.2,128.4,121.0$, 119.0, 117.9, 110.3, 109.8, 107.1, 56.5, 53.3, 49.4, 49.4, 47.0, 42.5, $40.8,38.7,38.3$, 37.1, 34.1, 33.6, 32.2, 31.6, 30.9, 29.9, 25.7, 23.1, 22.6, 21.5, 19.4, 19.2, 16.3, 15.9, 14.8; FTIR ( $\left.\nu, \mathrm{cm}^{-1}\right): 738,885$, 907, 1459, 1693, 2873, 2843; HRMS: $m / z$ calcd for $\mathrm{C}_{36} \mathrm{H}_{50} \mathrm{NO}_{2}$ 528.3842, found $528.3838[\mathrm{M}+\mathrm{H}]^{+}$. NMR spectral data are consistent with those previously reported. ${ }^{22}$

Lupa-2,20(29)-dieno[2,3-b]pyrazin-28-oic acid (5). A mixture of betulonic acid $(0.20 \mathrm{~g}, 0.44 \mathrm{mmol}), 1,2$-diaminoethane (130 mg, $2.0 \mathrm{mmol}$ ), sulfur (130 mg, $4.1 \mathrm{mmol}$ ) and morpholine $(4 \mathrm{~mL})$ was refluxed for $21 \mathrm{~h}$. Water was added and the resulting mixture was extracted with $\mathrm{CH}_{2} \mathrm{Cl}_{2}$. The organic phase was washed with $1 \mathrm{M}$ hydrochloric acid, water, a saturated aqueous solution of $\mathrm{NaHCO}_{3}$, water and brine, dried over anhydrous $\mathrm{Na}_{2} \mathrm{SO}_{4}$ and evaporated. The crude product was purified by $\mathrm{SiO}_{2}$ column chromatography (20-50\% EtOAc- $n$-hexane) to give a white crystalline solid $(147 \mathrm{mg}, 68 \%) .{ }^{13}{ }^{1} \mathrm{H}$ NMR $(300 \mathrm{MHz}$, $\left.\mathrm{CDCl}_{3}\right) \delta 8.42(\mathrm{~d}, J=2.4 \mathrm{~Hz}, 1 \mathrm{H}), 8.29(\mathrm{~d}, J=2.4 \mathrm{~Hz}, 1 \mathrm{H}), 4.76$ (s, 1H), 4.64 (s, 1H), $3.05(\mathrm{~m}, 2 \mathrm{H}), 2.46$ (d, J=16.5 Hz, 1H), 2.29 $(\mathrm{m}, 2 \mathrm{H}), 1.30(\mathrm{~s}, 3 \mathrm{H}), 1.72(\mathrm{~s}, 3 \mathrm{H}), 1.27(\mathrm{~s}, 3 \mathrm{H}), 1.04(\mathrm{~s}, 3 \mathrm{H}), 1.03$ $(\mathrm{s}, 3 \mathrm{H}), 0.81(\mathrm{~s}, 3 \mathrm{H}) ;{ }^{13} \mathrm{C}$ NMR $\left(75 \mathrm{MHz}, \mathrm{CDCl}_{3}\right) \delta 181.5,160.0$, 151.0, 150.5, 142.6, 141.5, 110.0, 56.6, 53.2 , 49.4, 49.0, 48.7, 47.1, $42.7,40.8,39.7,38.7,37.3,37.0,33.6,32.4,31.7,30.8,30.0,25.7$, 24.2, 21.6, 20.3, 19.7, 16.4, 15.9, 14.9; FTIR ( $\left.\nu, \mathrm{cm}^{-1}\right): 878,1107$, 1381, 1408, 1686, 2869, 2943; HRMS: $m / z$ calcd for $\mathrm{C}_{32} \mathrm{H}_{47} \mathrm{~N}_{2} \mathrm{O}_{2}$ 
491.3638, found 491.3637 $[\mathrm{M}+\mathrm{H}]^{+}$. ${ }^{1} \mathrm{H}$ NMR spectral data are consistent with those previously reported. ${ }^{23}$

Lupa-2,20(29)-dieno[2,3-d]pyrazin-28-amide (6). A mixture of lupa-2,20(29)-dieno[2,3- $d$ ]pyrazin-28-oic acid (141 mg, 0.28 mmol), oxalyl chloride ( $44 \mathrm{mg}, 0.34 \mathrm{mmol}$ ), and a drop of DMF in dry THF $(10 \mathrm{~mL})$ was stirred at room temperature for $2 \mathrm{~h}$. The solvent was evaporated, and the residue was dissolved in EtOAc. The organic phase was washed with a saturated aqueous solution of $\mathrm{NaHCO}_{3}$, water and brine, dried over anhydrous $\mathrm{Na}_{2} \mathrm{SO}_{4}$ and evaporated. The resulting crude lupa-2,20(29)-dieno[2,3- $b]$ pyrazin-28-oyl chloride was dissolved in $\mathrm{CHCl}_{3}(5 \mathrm{~mL})$, and a water solution of $25 \%$ ammonia $(2 \mathrm{~mL})$ was added to the mixture. The resulting solution was stirred at room temperature for $30 \mathrm{~min}$ and evaporated to dryness to give a white crystalline solid (137 mg, quant.). ${ }^{14}{ }^{1} \mathrm{H}$ NMR (300 $\left.\mathrm{MHz}, \mathrm{CDCl}_{3}\right) \delta 8.46$ $(\mathrm{s}, 1 \mathrm{H}), 8.29(\mathrm{~d}, J=2.4 \mathrm{~Hz}, 1 \mathrm{H}), 5.30(\mathrm{br} \mathrm{s}, 2 \mathrm{H}), 4.77(\mathrm{~s}, 1 \mathrm{H}), 4.64$ $(\mathrm{s}, 1 \mathrm{H}), 3.72(\mathrm{q}, J=7.0 \mathrm{~Hz}, 1 \mathrm{H}), 3.12(\mathrm{~d}, J=17.0 \mathrm{~Hz}, 2 \mathrm{H}), 2.67-$ $2.40(\mathrm{~m}, 2 \mathrm{H}), 2.08-1.74(\mathrm{~m}, 5 \mathrm{H}), 1.71(\mathrm{~s}, 3 \mathrm{H}), 1.67-1.35(\mathrm{~m}, 13 \mathrm{H})$, $1.31(\mathrm{~s}, 3 \mathrm{H}), 1.30(\mathrm{~s}, 3 \mathrm{H}), 1.04(\mathrm{~s}, 3 \mathrm{H}), 1.03(\mathrm{~s}, 3 \mathrm{H}), 0.82(\mathrm{~s}, 3 \mathrm{H})$; ${ }^{13} \mathrm{C}$ NMR $\left(75 \mathrm{MHz}, \mathrm{CD}_{3} \mathrm{OD}\right) \delta 182.4,161.4,152.3,152.0,143.8$, 142.3, 110.0, 57.1, 54.3, 51.2, 50.1, 48.1, 43.7, 41.9, 40.62, 39.4, $39.1,37.9,34.6,34.3,31.9,31.8,30.7,27.0,24.4,22.8,21.2$, 19.6, 16.6, 16.3, 15.0; FTIR $\left(\nu, \mathrm{cm}^{-1}\right): 886,1107,1184,1402,1665$, 2869, 2948, 3044, 3129; HRMS: $m / z$ calcd for $\mathrm{C}_{32} \mathrm{H}_{48} \mathrm{~N}_{3} \mathrm{O}$ 489.3797, found 490.3796 [M+ H$]^{+}$.

4-Aza-3-oxohomolup-20(29)-en-28-oic acid (8). A mixture of betulonic acid $(0.20 \mathrm{~g}, 0.44 \mathrm{mmol})$, hydroxylamine hydrochloride $(290 \mathrm{mg}, 4.2 \mathrm{mmol})$, dry pyridine $(5 \mathrm{~mL})$ and methanol $(8 \mathrm{~mL})$ was refluxed for $16 \mathrm{~h}$. Water was added, and the precipitated 3-oximinolup-20(29)-en-28-oic acid 7 was filtered and collected (173 mg, 84\%). 3-Oximinolup-20(29)-en-28-oic acid 7 (86 $\mathrm{mg}, 0.18 \mathrm{mmol}$ ) was dissolved in $\mathrm{CH}_{2} \mathrm{Cl}_{2}(5 \mathrm{~mL})$, and the resulting solution cooled to the ice-water bath temperature. Trifluoroacetic anhydride $(1.0 \mathrm{~mL}, 7.1 \mathrm{mmol})$ was added to this solution and the resulting mixture was stirred at room temperature for $20 \mathrm{~h}$. The reaction mixture was washed with water, a saturated aqueous solution of $\mathrm{NaHCO}_{3}$ and brine, dried over anhydrous $\mathrm{Na}_{2} \mathrm{SO}_{4}$, and evaporated. The crude product was purified by $\mathrm{SiO}_{2}$ column chromatography $(0-10 \% \mathrm{MeOH}-$ $\mathrm{CH}_{2} \mathrm{Cl}_{2}$ ) to yield a white crystalline solid (28 mg, 33\%). ${ }^{16}{ }^{1} \mathrm{H}$ NMR $\left(300 \mathrm{MHz}, \mathrm{CDCl}_{3}\right) \delta 6.39(\mathrm{~s}, 1 \mathrm{H}), 4.73(\mathrm{~s}, 1 \mathrm{H}), 4.61(\mathrm{~s}, 1 \mathrm{H}), 2.99$ (m, 1H), 2.59-2.41 (m, 1H), 2.42-2.15 (m, 4H), 2.13-1.94 (m, 2H), 1.69 (s, 3H), 1.57-1.33 (m, 12H), 1.31 (s, 3H), $1.23(\mathrm{~s}, 3 \mathrm{H}), 1.03$ (s, 3H), 0.98 (s, 3H), 0.97 (s, 3H); $\left.{ }^{13} \mathrm{C} \mathrm{NMR} \mathrm{(75} \mathrm{MHz,} \mathrm{CDCl}_{3}\right) \delta$ 181.3, 177.5, 150.6, 109.9, 56.7, 56.5, 56.5, 53.2, 51.2, 49.3, 47.7, 42.8, 41.0, 40.5, 39.5, 38.8, 37.3, 33.9, 33.4, 32.3, 32.0, 30.8, 29.8, 27.2 26.1, 22.7, 22.3, 19.6, 18.5, 16.1, 14.8, 14.7; FTIR $\left(\nu, \mathrm{cm}^{-1}\right)$ : 731, 883, 1185, 1374, 1454, 1628, 1691, 2938, 3250; HRMS: $m / z$ calcd for $\mathrm{C}_{30} \mathrm{H}_{48} \mathrm{NO}_{3} 470.3634$, found $470.3630[\mathrm{M}+\mathrm{H}]^{+}$.

$\mathbf{1}^{\prime} \boldsymbol{H}$-Lup-20(29)-eno[2,3-b]pyridin-28-oic acid (9). A mixture of betulonic acid (100 mg, $0.22 \mathrm{mmol}$ ), propargylamine $(24 \mathrm{mg}$, $0.44 \mathrm{mmol}), \mathrm{Cu}(\mathrm{I}) \mathrm{Cl}(5.0 \mathrm{mg}, 0.050 \mathrm{mmol})$ and ethanol $(5 \mathrm{~mL})$ was refluxed for $17 \mathrm{~h}$. The resulting solution was filtered, evaporated, and the crude product was purified by $\mathrm{SiO}_{2}$ column chromatography (10-20\% EtOAc- $n$-hexane) to yield a crystalline solid (12 mg, 11\%). ${ }^{15}{ }^{1} \mathrm{H}$ NMR (300 MHz, $\left.\mathrm{CDCl}_{3}\right) \delta 8.47(\mathrm{~m}, 1 \mathrm{H})$, 7.27 (m, 1H), 7.02 (dd, $J=7.6,4.8 \mathrm{~Hz}, 1 \mathrm{H}), 4.75(\mathrm{~s}, 1 \mathrm{H}), 4.62$ (s, 1H), $3.10(\mathrm{~m}, 1 \mathrm{H}), 2.74(\mathrm{~d}, J=15.9 \mathrm{~Hz}, 1 \mathrm{H}), 2.32(\mathrm{~m}, 3 \mathrm{H}), 2.03$ $(\mathrm{m}, 2 \mathrm{H}), 1.70(\mathrm{~s}, 3 \mathrm{H}), 1.67-1.36(\mathrm{~m}, 13 \mathrm{H}), 1.32(\mathrm{~s}, 3 \mathrm{H}), 1.27$ $(\mathrm{s}, 3 \mathrm{H}), 1.02(\mathrm{~s}, 3 \mathrm{H}), 0.99(\mathrm{~s}, 3 \mathrm{H}), 0.78(\mathrm{~s}, 3 \mathrm{H}) .{ }^{13} \mathrm{C} \mathrm{NMR}(75 \mathrm{MHz}$, $\left.\mathrm{CDCl}_{3}\right) \delta 180.3,163.6,150.8,146.8,138.4$, 130.3, 121.1, 109.7, 56.6, 53.8, 49.5, 49.0, 47.12, 46.1, 42.7, 40.8, 39.6, 38.7, 37.2, $36.4,33.7,32.5,31.6,30.9,30.0,25.8,24.2$, 21.7, 20.4, 19.6, 16.0, 15.9, 14.8; FTIR $\left(\nu, \mathrm{cm}^{-1}\right): 1012,1045,1110,1132,1184,1457$, 2856, 2927, 2959; HRMS: $m / z$ calcd for $\mathrm{C}_{33} \mathrm{H}_{48} \mathrm{NO}_{2} 490.3685$, found $490.3683[\mathrm{M}+\mathrm{H}]^{+}$.

2-(Hydroxymethylene)-3-oxolup-20(29)-en-28-oic acid (12). A mixture of betulonic acid $(0.200 \mathrm{~g}, 0.440 \mathrm{mmol}), \mathrm{NaH}(60 \%$ dispersion in mineral oil, $0.490 \mathrm{~g}, 12.8 \mathrm{mmol}$ ) and dry THF $(10 \mathrm{~mL})$ was cooled to the ice-water bath temperature. To this solution ethyl formate $(0.749 \mathrm{~g}, 10.1 \mathrm{mmol})$ was added, the resulting mixture was warmed to room temperature and stirred overnight. A saturated aqueous solution of $\mathrm{NH}_{4} \mathrm{Cl}$ was added, and the resulting mixture was extracted with EtOAc, washed with water and brine, dried over anhydrous $\mathrm{Na}_{2} \mathrm{SO}_{4}$, and evaporated. The crude product was purified by $\mathrm{SiO}_{2}$ column chromatography $(10-50 \%$ EtOAc- $n$-hexane) to yield a white crystalline solid (127 mg, 60\%). ${ }^{1} \mathrm{H}$ NMR (300 MHz, $\left.\mathrm{CDCl}_{3}\right) \delta$ 14.85 (d, $J=2.6 \mathrm{~Hz}, 1 \mathrm{H}), 9.88$ (br s, $1 \mathrm{H}), 8.58$ (d, $J=2.6 \mathrm{~Hz}, 1 \mathrm{H})$, $4.75(\mathrm{~s}, 1 \mathrm{H}), 4.62(\mathrm{~s}, 1 \mathrm{H}), 3.01(\mathrm{~m}, 1 \mathrm{H}), 2.31(\mathrm{~m}, 3 \mathrm{H}), 2.09-1.80$ (m, 3H), $1.70(\mathrm{~s}, 3 \mathrm{H}), 1.46(\mathrm{~m}, 16 \mathrm{H}), 1.18(\mathrm{~s}, 3 \mathrm{H}), 1.08(\mathrm{~s}, 3 \mathrm{H})$, $1.00(\mathrm{~s}, 3 \mathrm{H}), 0.99(\mathrm{~s}, 3 \mathrm{H}), 0.83(\mathrm{~s}, 3 \mathrm{H})$.

Lupa-2,20(29)-dieno[2,3- $d$ ] isoxazol-28-oic acid (10). A mixture of 2-(hydroxymethylene)-3-oxolup-20(29)-en-28-oic acid $(0.091 \mathrm{~g}, 0.18 \mathrm{mmol})$, hydroxylamine hydrochloride $(0.036 \mathrm{~g}$, $0.52 \mathrm{mmol})$ and acetic acid $(10 \mathrm{~mL})$ was refluxed for $3 \mathrm{~h}$. Water was added, and the resulting mixture was extracted with EtOAc, washed with a saturated aqueous solution of $\mathrm{NaHCO}_{3}$, water, and brine, dried over anhydrous $\mathrm{Na}_{2} \mathrm{SO}_{4}$, and evaporated to give a white solid (59 mg, 68\%). ${ }^{12} \mathrm{H}$ NMR (300 MHz, $\left.\mathrm{CDCl}_{3}\right) \delta 10.92$ (br s, 1H), $7.97(\mathrm{~s}, 1 \mathrm{H}), 4.75(\mathrm{~s}, 1 \mathrm{H}), 4.63(\mathrm{~s}, 1 \mathrm{H}), 3.09-2.92$ (m, 1H), 2.47 (d, $J=15.1 \mathrm{~Hz}, 1 \mathrm{H}), 2.36-2.19$ (m, 3H), 2.06-1.88 $(\mathrm{m}, 3 \mathrm{H}), 1.70(\mathrm{~s}, 3 \mathrm{H}), 1.60-1.33(\mathrm{~m}, 15 \mathrm{H}), 1.28(\mathrm{~s}, 3 \mathrm{H}), 1.19$ $(\mathrm{s}, 3 \mathrm{H}), 1.01(\mathrm{~s}, 3 \mathrm{H}), 0.99(\mathrm{~s}, 3 \mathrm{H}), 0.81(\mathrm{~s}, 3 \mathrm{H}) ;{ }^{13} \mathrm{C} \mathrm{NMR}(75 \mathrm{MHz}$, $\left.\mathrm{CDCl}_{3}\right) \delta 181.3,173.0,150.3,150.3,109.8,108.9,56.4,53.6,49.2$, 49.1, 46.9, 42.5, 40.8, 39.0, 38.5, 37.0, 35.9, 34.8, 33.4, 32.1, 30.6, 29.8, 28.7, 25.5, 21.4, 21.2, 19.4, 18.8, 16.1, 15.8, 14.7; FTIR $\left(\nu, \mathrm{cm}^{-1}\right): 733,881,1181,1375,1454,1695,2875,2940$; HRMS: $m / z$ calcd for $\mathrm{C}_{31} \mathrm{H}_{46} \mathrm{NO}_{3} 480.3478$, found $480.3478[\mathrm{M}+\mathrm{H}]^{+}$. NMR spectral data are consistent with those previously reported. $^{24}$

$\mathbf{1}^{\prime}$ H-Lup-20(29)-eno[3,2-c]pyrazol-28-oic acid (11). A mixture of 2-(hydroxymethylene)-3-oxolup-20(29)-en-28-oic acid (53 mg, $0.11 \mathrm{mmol})$, hydrazine hydrate $(16 \mathrm{mg}, 0.31 \mathrm{mmol})$ and toluene $(20 \mathrm{~mL})$ was refluxed at $150{ }^{\circ} \mathrm{C}$ under Dean-Stark conditions overnight. After cooling the reaction mixture to room temperature, the solvent was evaporated, and the resulting crude product was purified by $\mathrm{SiO}_{2}$ column chromatography (1-10\% EtOAc- $n$-hexane) to give a white crystalline solid (42 mg, 80\%). ${ }^{17}$ ${ }^{1} \mathrm{H}$ NMR (300 MHz, CD $\left.{ }_{3} \mathrm{OD}\right) \delta 7.16(\mathrm{~s}, 1 \mathrm{H}), 4.72(\mathrm{~s}, 1 \mathrm{H}), 4.60$ $(\mathrm{s}, 1 \mathrm{H}), 3.04(\mathrm{~m}, 1 \mathrm{H}), 2.64(\mathrm{~d}, J=14.8 \mathrm{~Hz}, 1 \mathrm{H}), 2.46-2.18(\mathrm{~m}, 2 \mathrm{H})$, $1.91(\mathrm{~m}, 2 \mathrm{H}), 1.70(\mathrm{~s}, 3 \mathrm{H}), 1.65-1.33(\mathrm{~m}, 11 \mathrm{H}), 1.26(\mathrm{~s}, 3 \mathrm{H}), 1.17$ $(\mathrm{s}, 3 \mathrm{H}), 1.04(\mathrm{~s}, 3 \mathrm{H}), 1.03(\mathrm{~s}, 3 \mathrm{H}), 0.80(\mathrm{~s}, 3 \mathrm{H}) ;{ }^{13} \mathrm{C} \mathrm{NMR}(75 \mathrm{MHz}$, $\left.\mathrm{CD}_{3} \mathrm{OD}\right) \delta 178.8,150.8,149.9,133.2,112.4,109.0,56.3,53.8$, 
49.4, 49.2, 47.3, 42.5, 40.8, 38.6, 36.9, 36.5, 33.6, 33.4, 32.1, 30.6, $30.1,29.8,25.8,22.8,21.4,19.1,18.4,15.3,15.2$, 14.0; FTIR $\left(\nu, \mathrm{cm}^{-1}\right): 883,960,1086,1184,1370,1452,1643,1695,2869$, $2943 ; \mathrm{m} / z$ calcd for $\mathrm{C}_{31} \mathrm{H}_{47} \mathrm{~N}_{2} \mathrm{O}_{2}$ : 479.3638; found $479.3638[\mathrm{M}+$ $\mathrm{H}]^{+}$. NMR spectral data are consistent with those previously reported. ${ }^{24}$

\section{Biology}

L. donovani (MHOM/SD/1962/1S-Cl2d) was used in all bioassays. Axenic amastigotes were grown at $37{ }^{\circ} \mathrm{C}$ in a $5 \% \mathrm{CO}_{2}$ incubator as described in complete RPMI 1640 containing 20\% fetal calf serum, pH 5.5. Screening of the compounds for leishmanicidal activity was carried out using the alamarBlue (AbD Serotec, Oxford, UK) viability assay similar to that reported for leishmanial promastigotes. Standardization and optimization of the assay for axenic amastigotes has been described elsewhere. ${ }^{25}$ Compounds to be assayed were diluted to twice the final concentration used in the assays in the complete amastigote medium, containing $1 \% \mathrm{DMSO}$, and were aliquoted in triplicate $(125 \mu \mathrm{L}$ per well) into 96-well flat-bottom plates (Nunc, Roskilde, Denmark). $\mathrm{IC}_{50}$ was determined using serial two-fold dilutions of the test compounds from 50 to $0.4 \mu \mathrm{M}$. Amastigotes $\left(5.0 \times 10^{5}\right.$ cells $\mathrm{mL}^{-1} ; 125 \mu \mathrm{L}$ per well) were added to each well and incubated for $24 \mathrm{~h}$ at $37^{\circ} \mathrm{C}$ in a $5 \% \mathrm{CO}_{2}$ incubator. The alamarBlue viability indicator was added $(25 \mu \mathrm{L}$ per well) and the plates incubated for an additional $24 \mathrm{~h}$ at which time the fluorescence $\left(\lambda_{\text {ex }}=544 \mathrm{~nm} ; \lambda_{\text {em }}=590 \mathrm{~nm}\right)$ was measured in a microplate reader (Fluoroskan Ascent FL, Finland). Complete medium both with and without DMSO was used as negative controls $(0 \%$ inhibition of amastigote growth). Amphotericin B (SigmaAldrich, St Louis MO), a drug used to treat VL, was included as a positive control on each plate and gave $>90 \%$ inhibition of parasite growth at $1 \mu \mathrm{M}$. Toxicity was measured on the human leukaemia monocyte cell line (THP-1 $6.4 \times 10^{4}$ cells per well) using the alamarBlue viability indicator as previously described..$^{26} \mathrm{IC}_{50}$ was determined using serial two-fold dilutions of the test compounds in triplicate from 500 to $0.25 \mu \mathrm{M}$. Inhibition of intracellular amastigote growth in infected THP-1 cells $\left(1.0 \times 10^{5}\right.$ cells per well) was carried out using transgenic Ld:pSSU-int/LUC promastigotes that express luciferase essentially as previously described. ${ }^{26}$ Amphotericin B $(1 \mu \mathrm{M})$ was included as a positive control on each plate. Complete medium both with and without DMSO was used as negative controls. Calculation of the $\mathrm{IC}_{50}$ 's and statistical analysis were carried out using GraphPad Prism Version 6.0b (GraphPad Software, Inc. San Diego, CA).

\section{Conclusions}

A set of betulin, betulinic acid and dihydrobetulinic acid derivatives, including eight new A-ring fused heterocycles, was synthesized and tested against $L$. donovani. Two heterocyclic compounds 5, 8, and potent anti-HIV drug candidate 25 had significant inhibition on parasite growth even at $5 \mu \mathrm{M}$ concentration. Compound $\mathbf{8}$ had the best selectivity index, and showed similar good activity on Leishmania-infected macrophages and axenic amastigotes. Further improvement and optimization are needed to get more potent betulin derivatives against L. donovani.

\section{Acknowledgements}

This study was supported by the European Commission (Contract no. EU-KBBE-227239-ForestSpeCs), the Academy of Finland (projects 252308, 264020, 265481) and The Finnish Cultural Foundation. DK was supported in part by the Michael and Penny Feiwel Foundation. We also thank Minni Pirttimaa, Dr Vânia Moreira and Dr Päivi Uutela for valuable discussions.

\section{Notes and references}

1 J. Alvar, I. D. Velez, C. Bern, M. Herrero, P. Desjeux, J. Cano, J. Jannin and M. den Boer, PLoS One, 2012, 7, e35671.

2 WHO, Leishmaniasis, World Health Organization, http:// www.who.int/leishmaniasis/en/index.html.

3 World Health Organization, Control of the leishmaniasis: report of a meeting of the WHO Expert Committee on the Control of Leishmaniases, Geneva, 22-26, March 2010, 2010, No. 949.

4 P. Desjeux, Comp. Immunol. Microbiol. Infect. Dis., 2004, 27, 305-318.

5 S. L. Croft, S. Sundar and A. H. Fairlamb, Clin. Microbiol. Rev., 2006, 19, 111-126.

6 T. P. C. Dorlo, M. Balasegaram, J. H. Beijnen and P. J. de Vries, J. Antimicrob. Chemother., 2012, 67, 2576-2597.

7 T. Kanamoto, Y. Kashiwada, K. Kanbara, K. Gotoh, M. Yoshimori, T. Goto, K. Sano and H. Nakashima, Antimicrob. Agents Chemother., 2001, 45, 1225-1230.

8 J. F. Mayaux, A. Bousseau, R. Pauwels, T. Huet, Y. Henin, N. Dereu, M. Evers, F. Soler, C. Poujade, E. De Clercq and J. B. Le Pecq, Proc. Natl. Acad. Sci. U. S. A., 1994, 91, 35643568.

9 P. K. Mukherjee, K. Saha, J. Das, M. Pal and B. P. Saha, Planta Med., 1997, 63, 367-369.

10 J. C. P. Steele, D. C. Warhurst, G. C. Kirby and M. S. J. Simmonds, Phytother. Res., 1999, 13, 115-119.

11 E. Pisha, H. Chai, I. S. Lee, T. E. Chagwedera, N. R. Farnsworth, G. A. Cordell, C. W. W. Beecher, H. H. S. Fong, A. D. Kinghorn, D. M. Brown, M. C. Wani, M. E. Wall, T. J. Hieken, T. K. Das Gupta and J. M. Pezzuto, Nat. Med., 1995, 1, 1046-1051.

12 S. Alakurtti, T. Heiska, A. Kiriazis, N. Sacerdoti-Sierra, C. L. Jaffe and J. Yli-Kauhaluoma, Bioorg. Med. Chem., 2010, 18, 1573-1582.

13 J.-F. Li, Y. Zhao, M.-M. Cai, X.-F. Li and J.-X. Li, Eur. J. Med. Chem., 2009, 44, 2796-2806.

14 O. B. Flekhter, E. I. Boreko, L. R. Nigmatullina, E. V. Tret'yakova, N. I. Pavlova, L. A. Baltina, S. N. Nikolaeva, O. V. Savinova, V. F. Eremin, F. Z. Galin and G. A. Tolstikov, Russ. J. Bioorg. Chem., 2004, 30, 80-88.

15 G. Abbiati, A. Arcadi, G. Bianchi, S. Di Giuseppe, F. Marinelli and E. Rossi, J. Org. Chem., 2003, 68, 6959-6966. 
16 H. Parra-Delgado, C. M. Compadre, T. Ramírez-Apan, M. J. Muñoz-Fambuena, R. L. Compadre, P. OstroskyWegman and M. Martínez-Vázquez, Bioorg. Med. Chem., 2006, 14, 1889-1901.

17 F. Fernández, O. Caamaño, M. D. García, I. Alkorta and J. Elguero, Tetrahedron, 2006, 62, 3362-3369.

18 Y. Wei, C.-M. Ma and M. Hattori, Eur. J. Med. Chem., 2009, 44, 4112-4120.

19 S. Alakurtti, P. Bergström, N. Sacerdoti-Sierra, C. L. Jaffe and J. Yli-Kauhaluoma, J. Antibiot., 2010, 63, 123126.

20 M. del Rayo Camacho, R. Mata, P. Castaneda, G. C. Kirby, D. C. Warhurst, S. L. Croft and J. D. Phillipson, Planta Med., 2000, 66, 463-468.
21 P. F. Smith, A. Ogundele, A. Forrest, J. Wilton, K. Salzwedel, J. Doto, G. P. Allaway and D. E. Martin, Antimicrob. Agents Chemother., 2007, 51, 3574-3581.

22 V. Kumar, N. Rani, P. Aggarwal, V. K. Sanna, A. T. Singh, M. Jaggi, N. Joshi, P. K. Sharma, R. Irchhaiya and A. C. Burman, Bioorg. Med. Chem. Lett., 2008, 18, 5058-5062.

23 M. Urban, J. Sarek, M. Kvasnica, I. Tislerova and M. Hajduch, J. Nat. Prod., 1997, 70, 526-532.

24 J. Xu, Z. Li, J. Luo, F. Yang, T. Liu, M. Liu, W.-W. Qiu and J. Tang, J. Med. Chem., 2012, 55, 3122-3134.

25 O. Shimony and C. L. Jaffe, J. Microbiol. Methods, 2008, 75, 196-200.

26 C. Reichwald, O. Shimony, U. Dunkel, N. Sacerdoti-Sierra, C. L. Jaffe and C. Kunick, J. Med. Chem., 2008, 51, 659-665. 